\title{
Total Thyroidectomy versus Bilateral Subtotal Thyroidectomy for Bilateral Multinodular Nontoxic Goiter: A Meta-Analysis
}

\author{
Yujie $\mathrm{Li}^{\mathrm{a}}$ Yangjun $\mathrm{Li}^{\mathrm{a}}$ Xiaodong Zhou ${ }^{\mathrm{b}}$ \\ aDepartment of Surgical Oncology, Ningbo No. 2 Hospital, and bepartment of Surgical \\ Oncology, Yuyao People's Hospital, Ningbo, China
}

\section{Key Words}

Total thyroidectomy · Bilateral subtotal thyroidectomy · Bilateral multinodular nontoxic goiter - Meta-analysis

\begin{abstract}
Aim: The aim of this meta-analysis is to assess and validate the feasibility and safety of total thyroidectomy (TT) when compared to bilateral subtotal thyroidectomy (BST) for bilateral multinodular nontoxic goiter (BMNG). Materials and Methods: PubMed, Web of Knowledge, and Ovid's database were searched for studies published in English language between January 1990 and December 2014. A meta-analysis was performed to compare the complications and recurrences of TT versus BST. The search terms used were 'total thyroidectomy', 'bilateral subtotal thyroidectomy', 'multinodular nontoxic goiter' and 'randomized clinical trial'. The reference lists of relevant studies were checked manually to locate any missing studies. Results: Four trials with a total of 1,078 patients were analyzed. Although the incidence of transient hypoparathyroidism was higher in TT than in BST (OR $=2.59,95 \%$ CI [1.58-4.24], $p=0.0002)$, TT was associated with a significantly lower incidence of recurrence $(O R=0.04,95 \%$ CI $[0.01$, 0.17], $p<0.0001$ ). There were no statistically significant differences for the presence of transient/permanent recurrent laryngeal nerve palsy and permanent hypoparathyroidism between the two groups. Conclusion: TT is a feasible and safe procedure for patients with BMNG. Although TT involves a significantly higher risk of postoperative transient hypoparathyroidism, it has a lower recurrence rate than BST.


Li et al.: Total Thyroidectomy versus Bilateral Subtotal Thyroidectomy for Bilateral Multinodular Nontoxic Goiter: A Meta-Analysis

The surgical procedure for bilateral multinodular nontoxic goiter (BMNG) remains controversial. Delbridge [1] reported that subtotal thyroidectomy for benign thyroid disease has been performed for more than a century and that it may reduce the associated risk of postoperative hypocalcemia and recurrent laryngeal nerve (RLN) palsy. However, it usually leads to high recurrence for BMNG patients in the long-term follow-up. Most surgeons still argue whether the potential risk of total thyroidectomy (TT) outweigh the potential benefits [2-5]. The management for BMNG intends to treat goiters that need surgical treatment and to reduce the risk of complications and recurrence [6-8]. In recent decades, TT has become a preferred surgical procedure for BMNG for the majority of surgeons [9] because it eliminates the risk of recurrence and there is no need reoperation for incidental differentiated thyroid cancer. However, this radical procedure may increase the risk of iatrogenic injury [4]. Some authors also discussed whether postoperative thyroid-stimulating hormone (TSH) suppression can prevent recurrence, but the conclusion was uncertain [10].

Up to the present time, no meta-analysis of randomized clinical trials has been performed to compare and summarize the results of TT with those of bilateral subtotal thyroidectomy (BST). The aim of this study is to assess and validate the safety and feasibility of TT when compared to BST and to verify other potential benefits and drawbacks for BMNG.

\section{Materials and Methods}

\section{Search Strategy}

PubMed, Web of Knowledge, and Ovid's database were searched for studies in English language published between January 1990 and December 2014. The search terms used were 'total thyroidectomy', 'bilateral subtotal thyroidectomy', 'multinodular nontoxic goiter' and 'randomized clinical trial'. The reference lists of relevant studies were checked manually to locate any missing studies.

\section{Study Selection}

The identified studies were assessed for eligibility for inclusion in the review by scrutinizing their titles, abstracts and keywords. Studies were restricted to those published in English. Clinical studies concerning comparisons of any aspects between TT and BST for MNG were also included.

\section{Data Extraction}

Two coauthors (Yujie Li and X.Z.) independently selected studies for inclusion and exclusion and reached consensus when they did not agree initially. The following variables were recorded: authors, journal and year of publication, number of patients, age, transient RLN palsy, permanent RLN palsy, transient hypoparathyroidism, permanent hypoparathyroidism and recurrence. If necessary, the corresponding authors of the studies were contacted to obtain supplementary information.

Quality Assessment

The quality of the trials was assessed according to the Cochrane Handbook for Systematic Reviews of Interventions version 5.1.0 [11]. It contained the following aspects: randomization, allocation concealment, blinding, description of withdrawals, and selective outcome reporting.

Trials which did not cover the outcomes of completely randomized patients were regarded as suffering from bias because of incomplete outcome data and were thus excluded from further analysis.

\section{Statistical Analysis}

A formal meta-analysis was carried out for all included studies comparing the results of TT and BST for BMNG. The outcomes in our study were transient RLN palsy, permanent RLN palsy, transient hypoparathyroidism, permanent hypoparathyroidism and recurrence. A fixed-effects model was used to calculate a pooled odds ratio (OR) with its $95 \%$ confidence interval (CI). Heterogeneity was explored using $\mathrm{I}^{2}$ statistics, a measure of how much the variance between studies, rather than chance, can be attributed to inter-study differences. $\mathrm{I}^{2}>50 \%$ was regarded to indicate strong heterogeneity. The Cochrane Collaboration's Review Manager Software (RevMan version 5.0) was utilized for data analysis. 
Li et al.: Total Thyroidectomy versus Bilateral Subtotal Thyroidectomy for Bilateral Multinodular Nontoxic Goiter: A Meta-Analysis

Fig. 1. Flowchart of the results of the literature search.

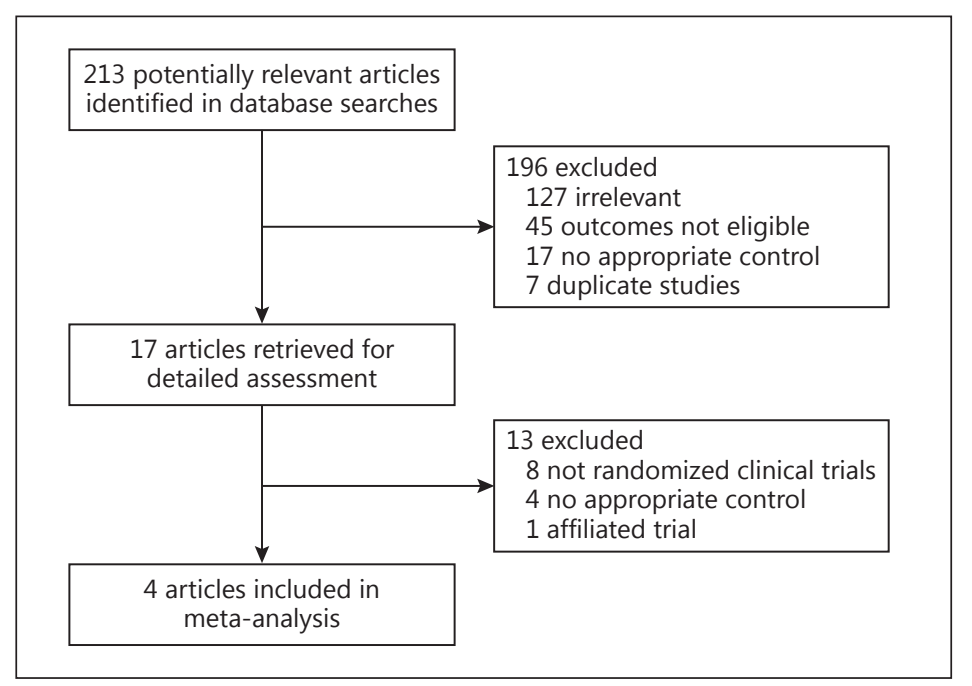

Table 1. Overview of the reviewed studies

\begin{tabular}{|c|c|c|c|c|c|c|c|}
\hline $\begin{array}{l}\text { First author } \\
\text { [Ref.], year }\end{array}$ & Country & $\begin{array}{l}\text { Patients, } \\
\mathrm{n}\end{array}$ & $\begin{array}{l}\text { Sex (male/ } \\
\text { female) }\end{array}$ & Patient source & $\begin{array}{l}\text { Mean age, } \\
\text { years }\end{array}$ & Levothyroxine therapy & $\begin{array}{l}\text { Study } \\
\text { design }\end{array}$ \\
\hline $\begin{array}{l}\text { Barczyńsk } \\
{[12], 2010}\end{array}$ & Poland & 381 & $\begin{array}{l}\text { TT: } 17 / 174 \\
\text { BST: } 16 / 174\end{array}$ & $\begin{array}{l}\text { Jagiellonian University } \\
\text { College of Medicine }\end{array}$ & $\begin{array}{l}\text { TT: } 46.5 \\
\text { BST: } 47.2\end{array}$ & $\begin{array}{l}\text { TT: mean } 100.59 \mu \mathrm{g} / \text { day } \\
\text { BST: mean } 77.16 \mu \mathrm{g} / \text { day }\end{array}$ & RCT \\
\hline $\begin{array}{l}\text { Giles [7], } \\
2004\end{array}$ & Turkey & 218 & $\begin{array}{l}\text { TT: } 15 / 94 \\
\text { BST: } 17 / 92\end{array}$ & $\begin{array}{l}\text { Istanbul Medical } \\
\text { Faculty }\end{array}$ & $\begin{array}{l}\text { TT: } 50.3 \\
\text { BST: } 45.7\end{array}$ & - & RCT \\
\hline $\begin{array}{l}\text { Yang [13], } \\
2009\end{array}$ & China & 346 & $\begin{array}{l}\text { TT: } 36 / 129 \\
\text { BST: } 42 / 139\end{array}$ & Ruijin Hospital & - & $\begin{array}{l}\text { TT: } 50-75 \mu \mathrm{g} / \text { day } \\
\text { BST: } 75-125 \mu \mathrm{g} / \text { day }\end{array}$ & RCT \\
\hline $\begin{array}{l}\text { Pappalardo } \\
{[14], 1998}\end{array}$ & Italy & 141 & $\begin{array}{l}\text { TT: } 20 / 49 \\
\text { BST: } 21 / 51\end{array}$ & University hospital & $\begin{array}{l}\text { TT: } 48.0 \\
\text { BST: } 50.0\end{array}$ & $\begin{array}{l}1.5-2.25 \mathrm{ug} / \mathrm{kg} \text {, subsequently } \\
\text { adjusted depending on TSH }\end{array}$ & RCT \\
\hline
\end{tabular}

RCT $=$ Randomized clinical trial.

\section{Results}

\section{Study Selection}

We identified 213 potentially relevant articles (fig. 1). After exclusion of duplicate references, nonrelevant literature, and articles that did not meet the inclusion criteria, 17 candidate articles were considered for the meta-analysis. After careful review of the full text of these articles, 4 studies were included. The study characteristics are summarized in tables 1 and 2.

Patient demographics for the 4 studies are presented in table 1 . All papers were randomized clinical trials. The publication dates ranged from 1990 to 2014. Study sizes ranged from 141 to 381 patients.

\section{Outcome Measures}

A total of 528 patients who underwent TT and 550 patients who underwent BST were analyzed. In the included studies, more than $2 \mathrm{~g}$ of normal remnant thyroid tissue on both sides of the neck was left in the BST group. The criteria for the recurrences are summarized in table 2 . 
Li et al.: Total Thyroidectomy versus Bilateral Subtotal Thyroidectomy for Bilateral

Multinodular Nontoxic Goiter: A Meta-Analysis

Table 2. Overview of the reviewed studies

\begin{tabular}{|c|c|c|c|c|}
\hline $\begin{array}{l}\text { First author } \\
\text { [Ref.], year }\end{array}$ & Inclusion criteria & Exclusion criteria & $\begin{array}{l}\text { Criteria used for } \\
\text { recurrences }\end{array}$ & $\begin{array}{l}\text { Median } \\
\text { follow-up, } \\
\text { months }\end{array}$ \\
\hline $\begin{array}{l}\text { Barczyńsk } \\
{[12], 2010}\end{array}$ & $\begin{array}{l}\text { A bilateral nontoxic MNG } \\
\text { with the posterior aspects } \\
\text { of both thyroid lobes } \\
\text { appearing normal on } \\
\text { ultrasound of the neck }\end{array}$ & $\begin{array}{l}\text { MNG involving the posterior } \\
\text { aspect/s of thyroid lobe/s, } \\
\text { suspicion of thyroid cancer, } \\
\text { previous thyroid surgery, } \\
\text { thyroiditis, subclinical or clinically } \\
\text { overt hypothyroidism or } \\
\text { hyperthyroidism, pregnancy or } \\
\text { lactation, and age }<18 \text { or }>65 \text { years }\end{array}$ & $\begin{array}{l}\text { Presence of hypoechoic or hyperechoic } \\
\text { nodular pattern at least } 5 \text { mm in } \\
\text { diameter, identification of perinodular } \\
\text { hypoechogenic or hyperechogenic } \\
\text { halo, and presence of an anechoic } \\
\text { lesion with a reinforced posterior wall }\end{array}$ & 60 \\
\hline $\begin{array}{l}\text { Giles [7], } \\
2004\end{array}$ & $\begin{array}{l}\text { Bilateral multinodular } \\
\text { goiter, euthyroid and no } \\
\text { history of hyperthyroidism, } \\
\text { radiation exposure, or } \\
\text { familial thyroid cancer }\end{array}$ & $\begin{array}{l}\text { Preoperative or perioperative } \\
\text { suspicion of malignancy }\end{array}$ & - & - \\
\hline $\begin{array}{l}\text { Yang [13], } \\
2009\end{array}$ & $\begin{array}{l}\text { Bilateral multinodular } \\
\text { goiter }\end{array}$ & History of thyroidectomy & $\begin{array}{l}\text { De novo nodules more than } 3 \mathrm{~mm} \text { in } \\
\text { remnant thyroid by ultrasonography }\end{array}$ & $\begin{array}{l}\text { TT: } 36 \\
\text { BST: } 39\end{array}$ \\
\hline $\begin{array}{l}\text { Pappalardo } \\
{[14], 1998}\end{array}$ & $\begin{array}{l}\text { Unilateral and bilateral } \\
\text { multinodular euthyroid } \\
\text { goiters }\end{array}$ & $\begin{array}{l}\text { Graves' disease, Plummer disease, } \\
\text { thyroiditis, hyperfunctioning single } \\
\text { adenoma, or cancer }\end{array}$ & $\begin{array}{l}\text { Physical examination or ultrasound } \\
\text { scan showed nodular involvement or } \\
\text { an enlargement of the residual thyroid } \\
\text { remnant }\end{array}$ & 174 \\
\hline
\end{tabular}

Transient RLN palsy was observed in 4 studies. The BST group had less transient RLN palsy, but no significant difference was found (OR $=1.68,95 \%$ CI $[0.75,3.74], p=0.21$; fig. 2 ). The prevalence of permanent RLN palsy was $0.77 \%$ in the TT group versus $0.76 \%$ in the BST group without a significant difference (OR $=1.01,95 \%$ CI [0.17-5.92], $p=0.99$; fig. 2). All 4 studies assessed patients for transient hypoparathyroidism. The prevalence of transient hypoparathyroidism was $11.0 \%$ in the TT group versus $4.9 \%$ in the BST group, and this difference was statistically significant (OR $=2.59,95 \% \mathrm{CI}$ [1.58-4.24], $\mathrm{p}=0.0002$; fig. 2). The prevalence of permanent hypoparathyroidism was $0.6 \%$ in the TT group versus $0.2 \%$ in the BST group, and no significant difference was observed (OR $=2.42,95 \%$ CI [0.35-16.64], $\mathrm{p}=$ 0.37; fig. 2). Recurrence was assessed in 3 of the 4 studies. The recurrence rate in BST was approximately $10 \%$ and significantly higher than that in TT (OR $=0.04,95 \%$ CI $[0.01,0.17]$, $\mathrm{p}<0.0001$; fig. 3). The incidence of thyroid cancer was lower in the BST group, but no significant difference was found (OR $=1.35,95 \%$ CI [0.79-2.30], $\mathrm{p}=0.27$; fig. 4).

\section{Discussion}

There are several surgical procedures for BMNG, including subtotal thyroidectomy, neartotal thyroidectomy, and TT. The postoperative complications (transient/permanent hypocalcemia and transient/permanent RLN palsy) and recurrences are regarded as the assessment of the balance between TT and ST.

In the past several years, a lot of data has been published indicating the equal incidence of both transient/permanent RLN palsy and transient/permanent hypocalcemia for subtotal thyroidectomy and TT $[3,15,16]$. According to the research of Randolph [17], the incidence of transient/permanent RLN palsy was $0-6 \%$ and $<1 \%$, respectively. The incidence of 
Li et al.: Total Thyroidectomy versus Bilateral Subtotal Thyroidectomy for Bilatera Multinodular Nontoxic Goiter: A Meta-Analysis

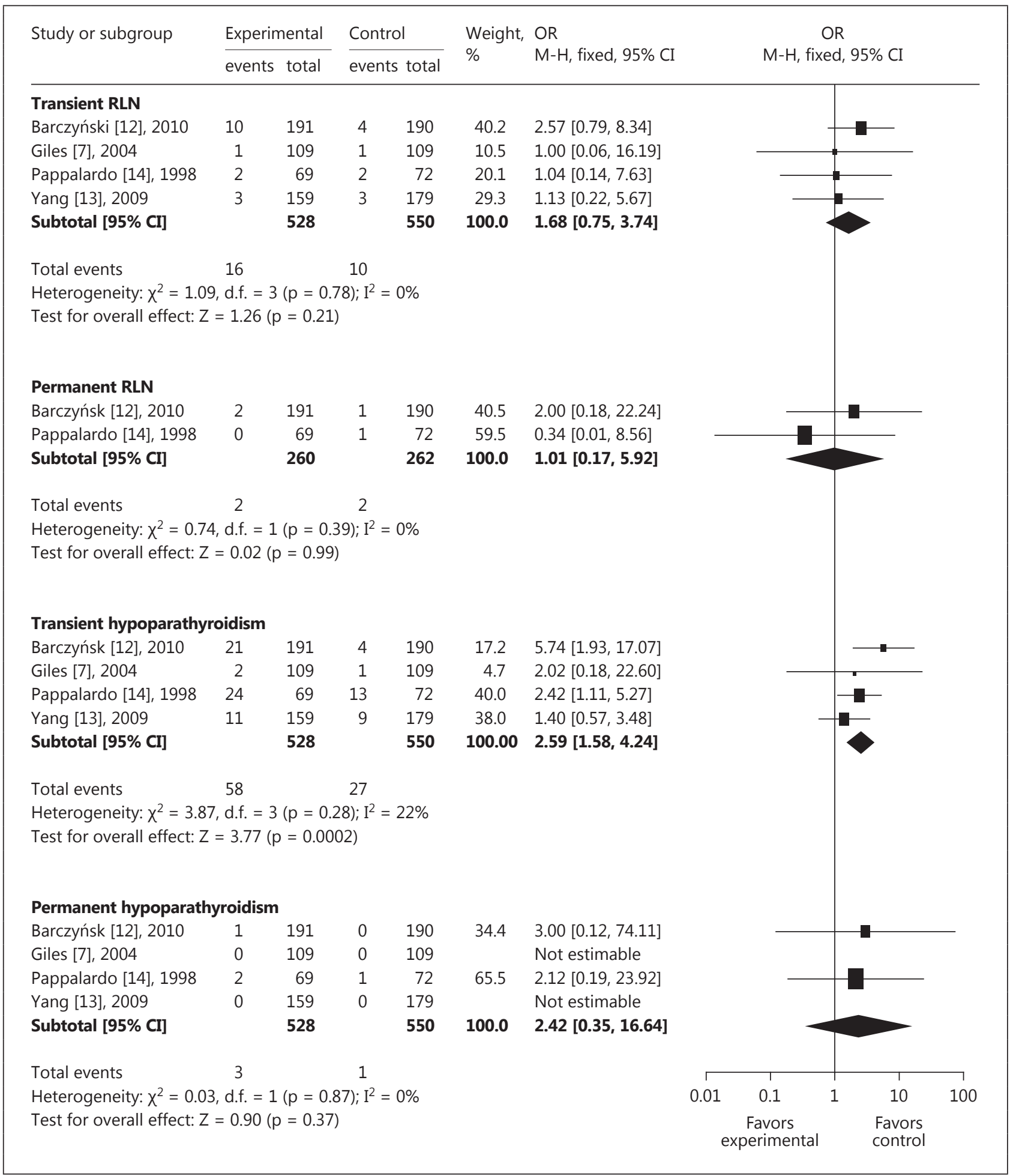

Fig. 2. Forest plot of the comparison of transient RLN, permanent RLN, transient hypoparathyroidism, and permanent hypoparathyroidism for TT versus BST. 
Li et al.: Total Thyroidectomy versus Bilateral Subtotal Thyroidectomy for Bilateral Multinodular Nontoxic Goiter: A Meta-Analysis

\begin{tabular}{|c|c|c|c|c|c|c|c|c|c|c|c|}
\hline \multirow{3}{*}{$\begin{array}{l}\text { Study or subgroup } \\
\text { Barczyńsk [12], } 2010\end{array}$} & \multirow{2}{*}{\multicolumn{2}{|c|}{$\begin{array}{l}\text { Experimental } \\
\text { events total }\end{array}$}} & \multirow{2}{*}{\multicolumn{2}{|c|}{$\frac{\text { Control }}{\text { events total }}$}} & \multirow{3}{*}{$\begin{array}{l}\text { Weight, } \\
\% \\
49.7\end{array}$} & \multirow{3}{*}{$\begin{array}{l}\text { OR } \\
\text { M-H, fixed, 95\% CI } \\
0.04[0.01,0.30]\end{array}$} & \multirow{2}{*}{\multicolumn{5}{|c|}{$\begin{array}{c}\text { OR } \\
M-H, \text { fixed, } 95 \% C I\end{array}$}} \\
\hline & & & & & & & & & & & \\
\hline & 1 & 191 & 22 & 190 & & & $\longleftarrow$ & & & & \\
\hline Pappalardo [14], 1998 & 0 & 69 & 10 & 72 & 23.1 & $0.04[0.00,0.75]$ & & & & & \\
\hline Yang [13], 2009 & 0 & 165 & 12 & 179 & 27.1 & $0.04[0.00,0.69]$ & & & & & \\
\hline Total $[95 \% \mathrm{CI}]$ & & 425 & & 441 & 100.0 & $0.04[0.01,0.17]$ & & & & & \\
\hline Total events & 1 & & 44 & & & & & & & & \\
\hline \multirow{2}{*}{\multicolumn{7}{|c|}{$\begin{array}{l}\text { Heterogeneity: } \chi^{2}=0.00, \text { d.f. }=2(p=1.00) ; I^{2}=0 \% \\
\text { Test for overall effect: } Z=4.40(p<0.0001)\end{array}$}} & 0.01 & 0.1 & & 10 & 100 \\
\hline & & & & & & & & $\begin{array}{l}\text { Favor } \\
\text { erime }\end{array}$ & & $\begin{array}{l}\text { Favors } \\
\text { control }\end{array}$ & \\
\hline
\end{tabular}

Fig. 3. Forest plot of the comparison of recurrence for TT versus BST.

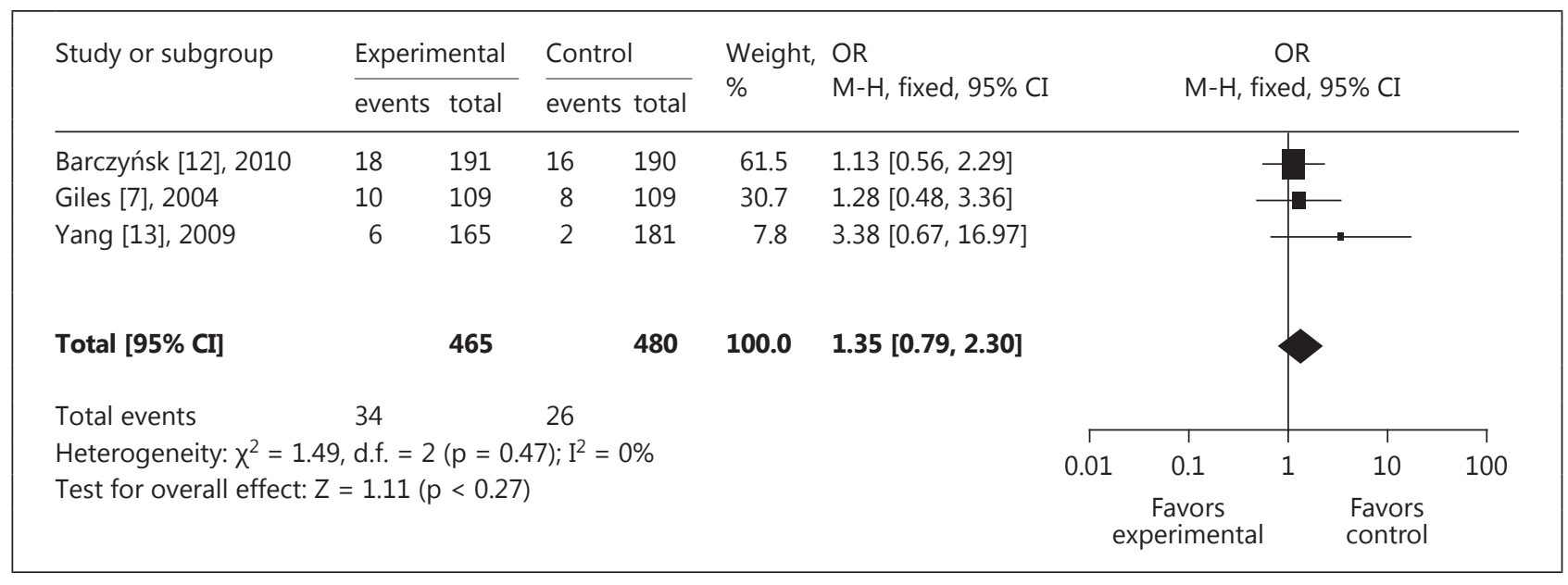

Fig. 4. Forest plot of the comparison of thyroid cancer incidence for TT versus BST.

transient/permanent hypocalcemia was $0.3-49 \%$ and $0-13 \%$, respectively. Thirteen studies $[3,7,14,16,18-26]$ were summarized by Agarwal and Aggarwal [9]: only 1 study [26] reported that the permanent RLN palsy rate was significantly higher, and merely 2 studies $[22,26]$ showed that the permanent hypocalcemia rate was significantly higher. Other studies did not find any significant difference in the incidence of permanent hypocalcemia and permanent RLN palsy after TT and BST.

In all 4 included studies, the incidence of transient/permanent RLN and transient/ permanent hypocalcemia was similar to that reported by Randolph [17]. Our meta-analysis showed that TT was of similar risk of complications compared with BST except for transient hypoparathyroidism. Patients with transient hypoparathyroidism can receive calcium substitution after surgery.

The rates of recurrence are considered as long-term therapeutic effect for BMNG. In some studies, the rates of recurrence of BMNG after BST ranged from $1.2 \%$ in a retrospective study [3] to $50 \%$ in another retrospective study [27], and the risk for recurrence was significantly higher in the BST group than in the TT group. Delbridge et al. [28] reviewed that subtotal 
Li et al.: Total Thyroidectomy versus Bilateral Subtotal Thyroidectomy for Bilatera Multinodular Nontoxic Goiter: A Meta-Analysis

thyroidectomy for multinodular goiter led to a second operation because of recurrence in $13-20 \%$ of patients, reaching a peak incidence 13 years after the primary operation. For these patients, the second operations are usually associated with higher complications in contrast with primary surgery $[28,29]$.

Incidental thyroid cancers have been detected in 3-16.6\% of apparently benign goiters after TT or BST in various studies [5, 9, 28, 30,31]. About two thirds of cancers are micropapillary or microinvasive follicular cancers $[3,19,27,32-35]$. Though the treatment of microcarcinomas is still a matter of discussion, some microcarcinomas may have a negative outcome, including distant metastasis and patient death [36-39]. Pellegriti et al. [40] detected local regional metastasis in one fourth of 299 carcinoma patients with tumors smaller than $1.5 \mathrm{~cm}$. The other third of cancers are follicular cancers and multicentric or large papillary cancers; such patients need further surgical treatment after subtotal thyroidectomy.

In our meta-analysis, the incidence of thyroid cancer was comparable between TT and BST (fig. 4). According to 3 included studies [12-14], the mean recurrence rate in BST was $10.0 \%$ (44/441), and TT faired significantly better than BST in terms of the frequency of recurrence. Therefore, TT was considered to be a valuable option for BMNG.

Furthermore, 3 included studies [12-14] reported levothyroxine requirements following thyroidectomy. Biological hypothyroidism occurred on average 5.6 months after surgery [41]. On monitoring thyroid function, patients with hypothyroidism received levothyroxine substitution following the operation. For those who received TT, the goal of therapy was euthyroidism, and the correct maintenance dose allowed TSH to be in the normal range. Thus, the quality of life was affected by levothyroxine reposition [42].

Several authors have hypothesized that postoperative levothyroxine therapy could hinder MNG recurrence by retronegative control of the production of TSH. However, this hypothesis is controversial. Moalem et al. [10] assessed that approximately $50 \%$ of studies on the subject support this hypothesis, but with sometimes questionable methodology. Some studies indicated that substitutive levothyroxine therapy does not have any influence on nodular recurrence $[41,43,44]$.

In case of unilateral disease, some studies recommended unilateral resection in both adults and children $[45,46]$. For unilateral resection, transient hypocalcemia was reported in $0-18 \%$ of patients, voice hoarseness in 1-6\%, and hematoma in $0-1 \%$; moreover, transient hypoparathyroidism is uncommon $[10,16,47,48]$. In addition, the large majority of patients with unilateral resection avoided lifelong thyroid replacement therapy [49], while this treatment was needed in all patients after bilateral resection to prevent hypothyroidism. So, we recommend that patients with unilateral, benign MNG be treated with unilateral resection.

In summary, our meta-analysis reviewed much of the literature published to date and demonstrated that TT has rates of complications similar to BST except for transient hypoparathyroidism. Patients with transient hypoparathyroidism can receive calcium substitution after surgery. However, the present study has some limitations. First, selection bias is the domain that could lead to a biased estimate of the procedural effects in this analysis. Second, there is no standard definition for recurrent goiter in the literature.

\section{Conclusions}

While TT obviates the need for completion thyroidectomy in incidentally found thyroid cancer and there is no difference in the rate of RLN palsy between the two methods, TT has a significantly lower rate of recurrence than BST. It may be presumptuous to suggest that TT is the right choice for all patients with BMNG. Further prospective randomized studies with long-term follow-up are required to validate the results of this meta-analysis. 
Li et al.: Total Thyroidectomy versus Bilateral Subtotal Thyroidectomy for Bilatera Multinodular Nontoxic Goiter: A Meta-Analysis

\section{References}

Delbridge L: Total thyroidectomy: the evolution of surgical technique. ANZ J Surg 2003;73:761-768

Liu Q, Djuricin G, Prinz RA: Total thyroidectomy for benign thyroid disease. Surgery 1998;123:2-7.

Ozbas S, Kocak S, Aydintug S, et al: Comparison of the complications of subtotal, near total and total thyroidectomy in the surgical management of multinodular goitre. Endocr J 2005;52:199-205.

4 Thomusch 0, Machens A, Sekulla C, et al: Multivariate analysis of risk factors for postoperative complications in benign goiter surgery: prospective multicenter study in Germany. World J Surg 2000;24:1335-1341.

5 Wheeler MH: Total thyroidectomy for benign thyroid disease. Lancet 1998;351:1526-1527.

6 Bellantone R, Lombardi CP, Bossola M, et al: Total thyroidectomy for management of benign thyroid disease: review of 526 cases. World J Surg 2002;26:1468-1471.

7 Giles Y, Boztepe H, Terzioglu T, et al: The advantage of total thyroidectomy to avoid reoperation for incidental thyroid cancer in multinodular goiter. Arch Surg 2004;139:179-182.

8 Bergamaschi R, Becouarn G, Ronceray J, et al: Morbidity of thyroid surgery. Am J Surg 1998;176:71-75.

9 Agarwal G, Aggarwal V: Is total thyroidectomy the surgical procedure of choice for benign multinodular goiter? An evidence-based review. World J Surg 2008;32:1313-1324.

10 Moalem J, Suh I, Duh QY: Treatment and prevention of recurrence of multinodular goiter: an evidence-based review of the literature. World J Surg 2008;32:1301-1312.

11 Higgins J, Green S: Cochrane Handbook for Systematic Reviews of Interventions. http://www.cochranehandbook.org/ (accessed in 2012).

12 Barczyński M, Konturek A, Hubalewska-Dydejczyk A, et al: Five-year follow-up of a randomized clinical trial of total thyroidectomy versus Dunhill operation versus bilateral subtotal thyroidectomy for multinodular nontoxic goiter. World J Surg 2010;34:1203-1213.

13 Yang W, Shao T, Ding J, et al: The feasibility of total or near-total bilateral thyroidectomy for the treatment of bilateral multinodular goiter. J Invest Surg 2009;22:195-200.

14 Pappalardo G, Guadalaxara A, Frattaroli FM, et al: Total compared with subtotal thyroidectomy in benign nodular disease: personal series and review of published reports. Eur J Surg 1998;164:501-506.

15 Zambudio AR, Rodríguez J, Riquelme J, et al: Prospective study of postoperative complications after total thyroidectomy for multinodular goiters by surgeons with experience in endocrine surgery. Ann Surg 2004; 240:18-25.

16 Colak T, Akca T, Kanik A, et al: Total versus subtotal thyroidectomy for the management of benign multinodular goiter in an endemic region. ANZ J Surg 2004;74:974-978.

17 Randolph GW: Surgery of the Thyroid and Parathyroid Gland. Philadelphia, Saunders, 2003, pp 434-439.

18 Reeve TS, Delbridge L, Cohen A, et al: Total thyroidectomy. The preferred option for multinodular goiter. Ann Surg 1987;206:782-786.

19 Marchesi M, Biffoni M, Tartaglia F, et al: Total versus subtotal thyroidectomy in the management of multinodular goiter. Int Surg 1998;83:202-204.

20 Zaraca F, Di Paola M, Gossetti F, et al: Benign thyroid disease: 20-year experience in surgical therapy (in Italian). Chir Ital 2000;52:41-47.

21 La Gamma A, Letoquart JP, Kunin N, et al: Nodular goiter. Retrospective analysis of 608 cases (in French). J Chir (Paris) 1993;130:391-396.

22 Alimoglu O, Akdag M, Sahin M, et al: Comparison of surgical techniques for treatment of benign toxic multinodular goiter. World J Surg 2005;29:921-924.

23 De Toma G, Tedesco M, Gabriele R, et al: Total thyroidectomy in the treatment of multinodular toxic goiter (in Italian). G Chir 1995;16:373-376.

24 Müller PE, Kabus S, Robens E, et al: Indications, risks, and acceptance of total thyroidectomy for multinodular benign goiter. Surg Today 2001;31:958-962.

25 Koyuncu A, Dökmetas HS, Turan M, et al: Comparison of different thyroidectomy techniques for benign thyroid disease. Endocr J 2003;50:723-727.

26 Thomusch 0, Sekulla C, Dralle H: Is primary total thyroidectomy justified in benign multinodular goiter? Results of a prospective quality assurance study of 45 hospitals offering different levels of care (in German). Chirurg 2003;74:437-443.

27 Ríos A, Rodríguez JM, Galindo PJ, et al: Surgical treatment of multinodular goiter in young patients. Endocrine 2005;27:245-252.

28 Delbridge L, Guinea AI, Reeve TS: Total thyroidectomy for bilateral benign multinodular goiter: effect of changing practice. Arch Surg 1999;134:1389-1393.

29 Siragusa G, Lanzara P, Di Pace G: Subtotal thyroidectomy or total thyroidectomy in the treatment of benign thyroid disease: our experience. Minerva Chir 1998;53:233-238.

30 Tezelman S, Borucu I, Senyurek Giles Y, et al: The change in surgical practice from subtotal to near-total or total thyroidectomy in the treatment of patients with benign multinodular goiter. World J Surg 2009;33:400405.

31 Wilson DB, Staren ED, Prinz RA: Thyroid reoperations: indications and risks. Am Surg 1998;64:674-678; discussion 678-679.

32 Bellantone R, Lombardi CP, Bossola M, et al: Total thyroidectomy for management of benign thyroid disease: review of 526 cases. World J Surg 2002;26:1468-1471. 
Li et al.: Total Thyroidectomy versus Bilateral Subtotal Thyroidectomy for Bilateral Multinodular Nontoxic Goiter: A Meta-Analysis

33 Efremidou EI, Papageorgiou MS, Liratzopoulos N, et al: The efficacy and safety of total thyroidectomy in the management of benign thyroid disease: a review of 932 cases. Can J Surg 2009;52:39-44.

34 Mishra A, Agarwal A, Agarwal G, et al: Total thyroidectomy for benign thyroid disorders in an endemic region. World J Surg 2001;25:307-310.

35 Erbil Y, Bozbora A, Yanik BT, et al: Predictive factors for recurrent non-toxic goitre in an endemic region. J Laryngol Otol 2007;121:231-236.

36 Chow SM, Law SC, Chan JK, et al: Papillary microcarcinoma of the thyroid -prognostic significance of lymph node metastasis and multifocality. Cancer 2003;98:31-40.

37 Schlumberger M, Berg G, Cohen O, et al: Follow-up of low-risk patients with differentiated thyroid carcinoma: a European perspective. Eur J Endocrinol 2004;150:105-112.

38 Hay ID, Thompson GB, Grant CS, et al: Papillary thyroid carcinoma managed at the Mayo Clinic during six decades (1940-1999): temporal trends in initial therapy and long-term outcome in 2,444 consecutively treated patients. World J Surg 2002;26:879-885.

39 Pearce EN, Braverman LE: Papillary thyroid microcarcinoma outcomes and implications for treatment. J Clin Endocrinol Metab 2004;89:3710-3712.

40 Pellegriti G, Scollo C, Lumera G, et al: Clinical behavior and outcome of papillary thyroid cancers smaller than $1.5 \mathrm{~cm}$ in diameter: study of 299 cases. J Clin Endocrinol Metab 2004;89:3713-3720.

41 Akkari M, Schmitt D, Jeandel C, et al: Nodular recurrence and hypothyroidism following partial thyroidectomy for benign nodular thyroid disease in children and adolescents. Int J Pediatr Otorhinolaryngol 2014;78:17421746.

42 To J, Goldberg AS, Jones J, et al: A systematic review of randomized controlled trials for management of persistent post-treatment fatigue in thyroid cancer survivors. Thyroid 2015;25:198-210.

43 Hegedüs L, Nygaard B, Hansen JM: Is routine thyroxine treatment to hinder postoperative recurrence of nontoxic goiter justified? J Clin Endocrinol Metab 1999;84:756-760.

44 Berglund J, Bondesson L, Christensen SB, et al: Indications for thyroxine therapy after surgery for nontoxic benign goitre. Acta Chir Scand 1990;156:433-438.

45 Astl J, Dvoráková M, Vlcek P, et al: Thyroid surgery in children and adolescents. Int J Pediatr Otorhinolaryngol 2004;68:1273-1278.

46 Bauer PS, Murray S, Clark N, et al: Unilateral thyroidectomy for the treatment of benign multinodular goiter. J Surg Res 2013;184:514-518.

47 Ho TW, Shaheen AA, Dixon E, et al: Utilization of thyroidectomy for benign disease in the United States: a 15-year population-based study. Am J Surg 2011;201:570-574.

48 Friguglietti CU, Lin CS, Kulcsar MA: Total thyroidectomy for benign thyroid disease. Laryngoscope 2003;113: 1820-1826.

49 Stoll SJ, Pitt SC, Liu J, et al: Thyroid hormone replacement after thyroid lobectomy. Surgery 2009;146:554558; discussion 558-560. 